\title{
Implementation of Guidelines and Counseling Services in Managing Student Discipline in SDN 2 Jogomertan
}

\author{
Hesti Lestari, Dwi Puji Lestari, Joharman, Siti Fatimah \\ Universitas Sebelas Maret \\ lestarihesti129@gmail.com
}

\section{Article History}

accepted 24/09/2019

\begin{abstract}
This article aims to describe, 1) Discipline program planning through guidance and counseling services at SDN 2 Jogomertan, 2) Implementation of disciplinary programs through guidance and counseling services at SDN 2 Jogomertan, 3) Evaluation of discipline programs through guidance and counseling services at SDN 2 Jogomertan. This research is a descriptive study with the object of 1 school principal, 10 teachers and employees, and 10 students in grades 4, 5, and 6. The data analysis technique uses a qualitative descriptive approach. The results of the study, 1) Program planning is poured in a plenary meeting with all student guardians, parents' group meetings of each class, and school routine meetings, 2) Planting student discipline including coming to school on time, literacy before starting learning, discipline in doing homework, discipline to maintain environmental cleanliness, and regular prayer in congregation.

3) Evaluation of disciplinary programs is carried out at every report on program implementation (in the form of program reports, evaluation reports and follow-up to program implementation).

Keywords: counseling guidance, discipline, management
\end{abstract}

\begin{abstract}
Abstrak
Artikel ini bertujuan untuk mendeskripsikan, 1) Perencanaan program kedisiplinan melalui layanan bimbingan dan konseling di SDN 2 Jogomertan, 2) Pelaksanaan program kedisiplinan melalui layanan bimbingan dan konseling di SDN 2 Jogomertan, 3) Evaluasi program kedisiplinan melalui layanan bimbingan dan konseling di SDN 2 Jogomertan. Penelitian ini merupakan penelitian deskriptif dengan objek penelitian 1 kepala sekolah, 10 guru dan karyawan, dan 10 siswa kelas 4, 5, dan 6. Teknik analisis data menggunakan pendekatan deskriptif kualitatif. Hasil penelitian, 1) Perencanaan program dituangkan dalam rapat pleno dengan seluruh wali murid, rapat paguyuban wali murid tiap kelas, dan rapat rutinan sekolah, 2) Penanaman kedisiplinan siswa diantaranya adalah datang sekolah tepat waktu, literasi sebelum memulai pembelajaran, disiplin dalam mengerjakan PR, disiplin menjaga kebersihan lingkungan, dan pembiasaan sholat berjamaah.3) Evaluasi program kedisiplinan dilaksanakan pada setiap pembuatan laporan pelaksanaan program (berupa laporan program, laporan evaluasi dan tindak lanjut pelaksanaan program).
\end{abstract}

Kata kunci: : bimbingan konseling, kedisiplinan, pengelolaan

Social, Humanities, and Education Studies (SHEs): Conference Series https://jurnal.uns.ac.id/shes 


\section{PENDAHULUAN}

Pendidikan pada hakikatnya merupakan usaha sadar untuk pengembangan kepribadian yang berlangsung seumur hidup baik di sekolah maupun madrasah (Tohirin, 2007). Pendidikan membantu individu agar memiliki pribadi yang berkualitas. Terwujudkannya individu yang memiliki kepribadian yang optimal selaras dengan tujuan yang ingin dicapai dari layanan bimbingan dan konseling. Demi tercapainya tujuan tersebut, dalam setiap kegiatan pendidikan hendaknya peserta didik diarahkan untuk menciptakan pribadi yang berkembang secara optimal sesuai potensi dan karakteristik yang dimiliki masing-masing individu. Untuk menciptakan pribadi yang berkembang secara optimal, diperlukan kegiatan pendidikan yang menyeluruh dan tidak bersifat instruksional, namun meliputi kegiatan yang menjamin bahwa setiap peserta didik memperoleh layanan bimbingan agar mampu berkembang secara optimal.

Bimbingan merupakan suatu proses pemberian bantuan kepada individu yang dilakukan secara berkesinambungan, supaya individu tersebut dapat memahami dirinya, sehingga dia sanggup mengarahkan dirinya dan dapat bertindak secara wajar, sesuai dengan tuntutan dan keadaan lingkungan sekolah, keluarga, masyarakat dan kehidupan pada umumnya (Yusuf dan Nurihsan, 2005). Menurut Tohirin (2007), konseling adalah kontak atau hubungan timbal balik antara dua orang (konselor dan klien) untuk menangani masalah klien yang didukung oleh keahlian (expert) dalam suasana yang laras dan integrasi, berdasarkan norma-norma (kode etik) yang berlaku untuk tujuan yang berguna bagi klien. Dari uraian pengertian bimbingan dan pengertian koseling tersebut, dapat disimpulkan bahwa bimbingan dan konseling adalah suatu proses pemberian bantuan secara bekesinambungan oleh konselor kepada klien melalui hubungan timbal balik sehingga klien mampu menangani suatu permasalahannya dalam suasana yang laras dan integrasi sesuai norma-norma yang berlaku yang berguna bagi klien.

Pelaksanaan bimbingan dan konseling sangat diperlukan di sekolah dasar, karena dalam praktiknya tidak sedikit diantara peserta didik yang mengikuti proses belajar mengajar menghadapi masalah yang berasal dari dirinya sendiri dan lingkungan sekitarnya (Batubara dan Ariani, 2018). Perencanaan program, pelaksanaan program, dan evaluasi program layanan bimbingan dan konseling harus diperhatikan oleh sekolah. Bimbingan dan konseling membantu peserta didik untuk berkembang secara optimal dalam kepribadian dan akademiknya. Tugas dan tanggung jawab utama sebagai guru adalah mendidik dan mengajar peserta didik. Guru sebagai pengajar juga mempunyai fungsi sebagai pembimbing yang sudah terintegrasikan dalam proses pembelajaran yang mengarahkan aktivitas siswa sehingga terjadi proses belajar yang berkenaan juga dengan perubahan tingkah laku siswa meliputi aspek kognitif, afektif, dan psikomotorik. Dalam menjalankan tugas guru sebagai pengajar dan pembimbing, guru sebaiknya mampu memahami semua aspek kepribadian yang dimiliki masing-masing peserta didiknya.

Alasan pentingnya bimbingan dan konseling dalam pendidikan yaitu pendidikan merupakan usaha untuk mengembangkan kepribadian peserta didik, pendidikan berkembang secara dinamis yang selalu mengalami perubahan dan penyesuaian dalam berbagai komponen pendidikan, peran guru sebagai pendidik hendaknya mampu menggunakan berbagai pendekatan pribadi kepada siswa untuk mendidik melalui pemberian pelayanan bimbingan dan konseling sesuai dengan karakteristik masing-masing siswa. Untuk mencapai tujuan pelaksanaan bimbingan dan konseling, maka guru bimbingan dan konseling harus dibekali berbagai keahlian, seperti menguasai esensi pelayanan bimbingan dan konseling, kemampuan mengimplementasikan kolaborasi intern di tempat kerja, menguasai konsep dan praksis assessment untuk memahami kondisi, kebutuhan dan masalah konseli; menguasai kerangka teoritik dan praksis bimbingan dan konseling, keterampilan 
merancang program bimbingan dan konseling, keterampilan dalam mengimplementasikan program bimbingan dan konseling secara komprehensif, dan menilai proses dan hasil kegiatan layanan bimbingan dan konseling (Setyoningtyas, Mugiarso, \& Nusantoro, 2014). Seorang guru hendaknya mampu melaksanakan program bimbingan dan konseling secara terintegrasi dengan tujuan sistem pendidikan dengan kompetensi-kompetensi tersebut. Dalam hal ini, guru bimbingan dan konseling harus bekerjasama dengan kepala sekolah dan tenaga kependidikan sebagai pengelola di bidang layanan administrasi dan manajemen, guru sebagai pelaksana pembelajaran yang mendidik, dan orangtua peserta didik sebagai mitra sekolah (Irham, 2015). Setiap Sekolah Dasar idealnya harus memiliki seorang guru bimbingan dan konseling atau konselor. Dengan begitu, guru bimbingan dan konseling atau konselor tersebut dapat bekerjasama dengan guru kelas dan guru mata pelajaran dalam membantu peserta didik mencapai perkembangan optimal. Namun, pada kondisi belum tersedianya guru bimbingan dan konseling atau konselor di Sekolah Dasar maka penyelenggaraan bimbingan dan konseling dapat ditugaskan pada guru kelas terlatih atau kompeten (Farozin et al., 2016).

Layanan bimbingan dan konseling di sekolah dasar memiliki peran yang sangat penting untuk mengatasi berbagai masalah, seperti permasalahan yang banyak terjadi adalah masalah kedisiplinan siswa. Masalah disiplin merupakan masalah yang dihadapi sekolah-sekolah dewasa ini. Disiplin merupakan suatu sikap yang menunjukkan kesediaan untuk menepati atau mematuhi ketentuan, tata tertib, nilai serta kaidah-kaidah yang berlaku. Disiplin mengandung asas taat, yaitu kemampuan untuk bersikap dan bertindak secara konsisten berdasar pada suatu nilai tertentu. Dalam proses belajar mengajar, kedisiplinan dapat menjadi alat yang bersifat preventif untuk mencegah dan menjaga hal-hal yang dapat mengganggu dan menghambat proses belajar. Untuk itu berbagai peraturan ikut diberlakukan di sekolah-sekolah untuk menegakkan tingkat kedisiplinan.

Menurut Imron (dalam Wahyuni D, dkk: 2016) disiplin adalah suatu keadaan dimana sesuatu itu berada dalam keadaan tertib, teratur dan semestinya, serta tidak ada suatu pelanggaran-pelanggaran baik secara langsung atau tidak langsung. Dengan kata lain, konsep awal tentang disiplin terkait erat dengan perilaku yang sesuai dengan norma, yang dapat diamati dari luar. Mereka yang tidak mematuhi norma disebut sebagai berperilaku menyimpang (misbehavior) yang tampak dalam diri manusia, khususnya dalam diri anak muda. Kedisiplinan sekolah berfungsi sebagai alat pendidikan dan pembentuk sikap dan tingkah laku yang baik, yang nantinya dapat digunakan juga dalam lingkungan keluarga maupun lingkungan masyarakat. Dengan demikian kedisiplinan sebagai alat pendidikan adalah suatu tindakan, perbuatan yang dengan sengaja diterapkan untuk kepentingan pendidikan di sekolah.

SDN 2 Jogomertan merupakan salah satu sekolah dasar yang terdapat di Kabupaten Kebumen yang memiliki visi terwujudnya peserta didik yang sehat, cerdas, kompetitif, dan peduli lingkungan berdasarkan IMTAQ dan IPTEK. Salah satu misi SDN 2 Jogomertan adalah mengembangkan kepribadian yang berkarakter, untuk mewujudkan hal tersebut, sekolah mencanangkan suatu program kedisiplinan sebagai pembentuk karakter siswa melalui bimbingan dan konseling yang dilakukan sekolah.

Berdasarkan latar belakang di atas maka penulis membuat rumusan masalah dalam artikel ini adalah sebagai berikut 1) Bagaimana perencanaan program kedisiplinan melalui layanan bimbingan dan konseling di SDN 2 Jogomertan?; 2) Bagaimana pelaksanaan program kedisiplinan melalui layanan bimbingan dan konseling di SDN 2 Jogomertan?; 3) Bagaimana evaluasi program kedisiplinan melalui layanan bimbingan dan konseling di SDN 2 Jogomertan?. 


\section{METODE}

Penelitian yang digunakan adalah penelitian deskriptif kualitatif. Penelitian ini menggunakan teknik pengumpulan non tes yaitu menggunakan pengisian angket dan wawancara. Alat ukur yang digunakan berupa lembar angket dan lembar wawancara. Objek penelitian terdiri dari kepala sekolah, guru, dan siswa kelas 4, 5, dan 6 di SDN 2 Jogomertan. Teknik analisis data menggunakan teknik analisis deskriptif kualitatif.

Tahap penelitian dimulai dengan pengisian lembar angket yang diisi oleh siswa dan guru untuk mengetahui program kedisiplinan siswa di SDN 2 Jogomertan. Sampel siswa yang diambil untuk mengisi lembar angket sejumlah total 30 siswa yang masingmasing terdiri dari 10 siswa kelas 4,10 siswa kelas 5 , dan 10 siswa kelas 6 . Tahap selanjutnya adalah wawancara dengan kepala sekolah. Wawancara dilakukan untuk mengetahui secara umum implementasi perilaku sikap disiplin siswa dan mengetahui hambatan penerapan kedisiplinan siswa dan solusi yang diupayakan oleh kepala sekolah dan guru..

\section{HASIL DAN PEMBAHASAN}

Bimbingan konseling di SDN 2 Jogomertan memiliki program kedisiplinan yang bertujuan untuk melatih peserta didik agar mampu membangun budaya disiplin dan pembentukan karakter siswa. Pelaksanaan program kedisiplinan melalui layanan bimbingan dan konseling di SDN 2 Jogomertan belum dilakukan oleh tenaga profesional bimbingan dan konseling namun dilakukakan oleh guru wali kelas yang memiliki tugas rangkap sebagai wali kelas dan sebagai petugas atau guru BK. Wali kelas memiliki kedekatan dengan siswanya sehingga dapat mengetahui persoalan yang dihadapi siswa. Pelayanan bimbingan dan konseling juga dilakukan oleh guru mapel tertentu seperti guru agama dan kepala sekolah. Hal ini senada dengan pendapat Handayani (2018) menyatakan bahwa yang termasuk ke dalam petugas BK non-profesional di sekolah dan madrasah adalah: 1) Guru wali kelas yang selain memegang kelas tertentu diserahi tugas dan tanggung jawab sebagai petugas atau guru BK, 2) Guru pembimbing yaitu seorang guru yang selain mengajar pada mata pelajaran tertentu, terlibat juga dalam pelayanan bimbingan dan konseling, 3) Guru mata pelajaran tertentu yang diserahi tugas khusus menjadi petugas (guru BK), 4) Kepala sekolah (madrasah) yang bertanggung jawab atas sekurang-kurangnya 40 siswa.

Perencanaan program kedisiplinan dalam layanan bimbingan dan konseling di SDN 2 Jogomertan melalui program awal tahun ajaran melalui rapat pleno yang dihadiri oleh seluruh wali murid, komite, dan seluruh guru dan karyawan di SDN 2 Jogomertan. Selain itu, pembahasan perencanaan program kedisiplinan dilakukan pada saat rapat rutinan sekolah dan paguyuban wali murid oleh tiap kelas. Perencanaan antar program dilaksanakan dengan saling berkoordinasi dan dengan dibuat aturan kedisiplinan. Pentingnya aturan dalam budaya disiplin oleh Chiu \& Chow (2011) mengemukakan bahwa untuk menciptakan budaya disiplin di sekolah akan dipengaruhi salah satu faktor yaitu aturan sekolah dan norma-norma yang dapat memengaruhi disiplin kelas.

Sosialisasi program kedisiplinan dalam layanan bimbingan dan konseling di SDN 2 Jogomertan secara umum dilaksanakan oleh kepala sekolah, semua guru dan karyawan dengan cara membimbing, memberi nasihat, dan memberikan teladan yang baik kepada semua peserta didik. Pelaksanaan sosialisasi di dalam pembelajaran dilakukan oleh guru kelas maupun guru mapel dengan cara pendekatan kepada peserta didik, penyampaian program kedisiplinan saat upacara rutin hari Senin dan saat kegiatan rutin senam pagi di hari Jum'at. Sosialisasi program kedisiplinan kepada wali murid dilaksanakan saat rapat pleno dan rapat paguyuban wali murid masingmasing kelas. Penanaman kedisiplinan siswa SDN 2 Jogomertan diantaranya adalah siswa selalu diharuskan datang di sekolah tepat waktu, literasi sebelum memulai 
pembelajaran, disiplin dalam mengerjakan PR, disiplin menjaga kebersihan lingkungan seperti pembiasaan memungut minimal 20 sampah sebelum masuk kelas, dan pembiasaan sholat berjama'ah.

Hasil penanaman kedisiplinan melalui bimbingan dan konseling di SDN 2 Jogomertan memberikan hasil bahwa siswa di SDN 2 Jogomertan sudah membiasakan perilaku disiplin dalam kegiatan sehari-hari. Bentuk-bentuk perilaku disiplin yang sudah diterapkan diantaranya adalah siswa datang ke sekolah tepat waktu, membiasakan siswa berdo'a sebelum dan sesudah melakukan kegiatan belajar di sekolah, selalu tersenyum atau menyapa dan berjabat tangan ketika bertemu dengan guru, membiasakan siswa menghormati dan menghargai orang lain, siswa selalu berpakaian rapi ketika di sekolah, mengerjakan PR dengan tepat waktu, dan selalu belajar di rumah meskipun tidak ada ulangan. Melalui layanan bimbingan dan konseling, guru mengarahkan siswa untuk lebih disiplin mengembangkan kreativitas yang dimiliki siswa, memberikan dorongan siswa untuk lebih termotivasi dalam belajar, dan memberikan ulasan materi yang sudah diajarkan sebelumnya ketika memulai materi pelajaran baru.

Penanaman perilaku disiplin hendaknya ditanamkan sejak di sekolah dasar. Hal ini sesuai dengan teori yang dikemukakan oleh Elizabeth Hurlock (dalam Fiana, dkk. 2013) bahwa anak membutuhkan disiplin, bila mereka ingin bahagia dan menjadi orang yang baik penyesuaiannya, karena melalui disiplin mereka dapat belajar berperilaku dengan cara yang diterima masyarakat dan sebagai hasilnya diterima oleh anggota kelompok sosial. Dengan disiplin siswa mendapatkan dorongan motivasi, daya saing, dan kemampuan yang melahirkan individu yang unggul. Menciptakan kondisi lingkungan yang disiplin mampu membentuk perilaku siswa yang disiplin pula karena adanya hubungan interaksi antara situasi lingkungan dengan sikap dan faktorfaktor yang ada dalam diri siswa.

Evaluasi program kedisiplinan melalui layanan bimbingan dan konseling di SDN 2 Jogomertan dilaksanakan tinjauan perkembangan peserta didik melalui catatan harian guru, rapat rutin sekolah, saat pembagian laporan hasil belajar siswa tiap semester, dan saat rapat pleno di awal tahun ajaran. Selanjutnya hasil evaluasi dijadikan sebagai bahan untuk menentukan perencanaan dan perbaikan program kedisiplinan di SDN 2 Jogomertan agar lebih baik di masa yang akan datang. Hal ini sejalan dengan teori yang dikemukakan Munthe (2015) bahwa evaluasi program sebagai suatu proses pencarian informasi, penemuan informasi dan penetapan informasi yang dipaparkan secara sistematis tentang perencanaan, nilai, tujuan, manfaat, efektifitas dan kesesuaian sesuatu dengan kriteria dan tujuan yang telah ditetapkan. Evaluasi program kedisiplinan dilakukan dengan cara menemukan kekurangan-kekurangan dari program yang sudah berjalan yang kemudian dianalisis untuk dapat menentukan kebijakan yang selanjutnya.

Hasil evaluasi dari berjalannya program kedisiplinan dalam layanan bimbingan dan konseling di SDN 2 Jogomertan menunjukkan bahwa program kedisiplinan sudah berjalan dengan baik walaupun masih terdapat kendala-kendala. Kendala yang ditemui dalam menegakkan kedisiplinan siswa diantaranya adalah masih ada beberapa siswa yang melanggar peraturan sekolah, masih ada beberapa siswa yang terlambat masuk sekolah, masih ada siswa yang tidak mengerjakan tugas, dan masih ada siswa yang berpakaian tidak lengkap. Konsekuensi yang didapatkan siswa yang tidak disiplin adalah pemberian teguran oleh guru dengan cara menasihati siswa malalui pendekatan secara individu maupun kolompok, pemberian sanksi yang mendidik supaya tidak mengulangi kesalahannya seperti dengan membersihkan lingkungan sekolah, dan mengkomunikasikan pelanggaran yang dilakukan siswa kepada wali murid agar memberikan bimbingan dan arahan yang lebih baik untuk menjadikan siswa lebih disiplin. Kekurangan penanaman program kedisiplinan di SDN 2 Jogomertan yaitu program kedisiplinan belum terprogram secara khusus dalam program BK dan 
sebagian siswa masih belum melaksanakan program kedisiplinan dengan baik. Tindak lanjut dari pelaksanaan evaluasi program kedisiplinan di SDN 2 Jogomertan adalah mengkaji kekurangan dan kendala pelaksanaan program kedisiplinan melalui rapat rutin sekolah, rapat paguyuban wali murid siswa masing-masing kelas, dan rapat pleno untuk mendapatkan solusi dari permasalahan kedisiplinan di SDN 2 Jogomertan, merencanakan penyusunan program kedisiplinan siswa dalam program bimbingan dan konseling secara lebih terperinci, meningkatkan kerjasama dan koordinasi antara kepala sekolah, guru, dan wali murid untuk melakukan pembiasaan kedisiplinan pada siswa baik di lingkungan sekolah maupun di lingkungan keluarga dan masyarakat.

\section{SIMPULAN}

Pelayanan bimbingan dan konseling di SDN 2 Jogomertan dalam mengelola kedisiplinan bertujuan untuk melatih peserta didik agar mampu membangun budaya disiplin dan pembentukan karakter pada siswa. Perencanaan program dituangkan dalam rapat pleno di awal tahun ajaran baru, rapat rutinan sekolah, dan paguyuban wali murid masing-masing kelas. Pelaksanaan sosialisasi di dalam pembelajaran dilakukan oleh guru kelas maupun guru mapel, penyampaian program kedisiplinan secara umum dilakukakan saat kegiatan upacara dan senam pagi. Penyampaian sosialisasi program kedisiplinan kepada wali murid dilakukan pada saat rapat pleno dan rapat paguyuban wali murid masing-masing kelas.

Evaluasi program kedisiplinan dalam layanan bimbingan dan konseling di SDN 2 Jogomertan melalui catatan harian guru, rapat rutin guru setiap minggunya, saat pembagian laporan hasil belajar siswa tiap semester, dan saat rapat pleno di awal tahun ajaran. Hasil evaluasi menunjukkan bahwa program kedisiplinan sudah berjalan dengan baik walaupun masih terdapat kendala beberapa siswa yang belum mematuhi aturan dengan baik. Tindak lanjut dari pelaksanaan evaluasi program kedisiplinan adalah dengan merencanakan penyusunan program kedisiplinan siswa dalam program bimbingan dan konseling secara lebih terperinci, meningkatkan kerjasama dan koordinasi antara kepala sekolah, guru, dan wali murid untuk terus melakukan pembiasaan kedisiplinan pada siswa.

\section{DAFTAR PUSTAKA}

Batubara, H. H. dan Ariani D. N. (2018). Penyelenggaraan Bimbingan dan Konseling di Sekolah Dasar. Jurnal Pendidikan, Vol. 3, No. 4, Bln April, Thn 2018, Hal 447452.

Chiu, M.M., \& Chow, B.W.Y. (2011). "Classroom Discipline Across Forty-One Countries: School, Economic, And Cultural Differences". Journal Of CrossCultural Psychology, 42 (3), HIm. 516- 533.

Farozin, M., Suherman, U., Triyono, Purwoko, B., Hafina, A., Yustiana, Y. R., \& Sukmaja. (2016). Panduan Operasional Penyelenggaraan Bimbingan dan Konseling Sekolah Dasar (SD). Jakarta: Direktorat Jenderal Guru dan Tenaga Kependidikan Kementerian Pendidikan dan Kebudayaan Republik Indonesia.

Fiana, F.J, Daharnis, Ridha, M. dkk. (2013). Disiplin Siswa di Sekolah dan Implikasinya dalam Pelayanan Bimbingan dan Konseling. Konselor Jurnal Ilmiah Konseling. Volume 2 Nomor 23 April 2013.

Handayani, Kiki Tri. (2018). Peran guru bimbingan dan konseling dalam mengatasi siswa bermasalah di madrasah tsanawiyah swasta al-azis rantauprapat labuhanbatu. Skripsi thesis, Universitas Negeri Islam Sumatra Utara.

Irham, M. (2015). Model Manajemen Bimbingan dan Konseling di Sekolah Dasar (Studi Kasus di SD Al-Irsyad Al Islamiyyah Purwokerto). IAIN Purwokerto.

Munthe, A. P. (2015). Pentingya Evaluasi Program di Institusi Pendidikan: Sebuah Pengantar, Pengertian, Tujuan dan Manfaat. Disampaikan dalam Workshop 
untuk Mahasiswa tentang Penelitian Metode Kuantitatif dan Kualitatif di Fakultas IImu Pendidikan UPH, Karawaci, 16 dan 23 Juni 2015.

Setyoningtyas, R., Mugiarso, H., \& Nusantoro, E. (2014). Persepsi Guru BK tentang Kompetensi Konselor di Sekolah Dasar Swasta Kota Semarang. Indonesian Journal of Guidance and Counseling : Theory and Application, 3(2), 37-39.

Tohirin. (2007). Bimbingan dan Konseling di Sekolah dan Madrasah. Jakarta: PT RajaGrafindo Persada.

Wahyuni, D. dkk. (2016). Hubungan Kedisiplinan Terhadap Hasil Belajar Siswa Kelas V Di SD Negeri 10 Banda Aceh. Jurnal IImiah Mahasiswa Prodi PGSD FKIP Unsyiah Volume $1 \quad$ Nomor 1, 21-29 Agustus 2016.

Yusuf dan Nurihsan. (2005). Landasan Bimbingan dan Konseling. Bandung: PT Remaja Rosdakarya. 